\title{
Financing for Development and Socio-Ecological Transitions: A Review of Chinese Investments in Kenya
}

\author{
Antony Kamakia (Corresponding author) \\ National Research Centre for Resettlement, Hohai University \\ 8 focheng west road, Jiangning District 211100, Nanjing, Jiangsu, China \\ Tel: 86-151-9575-0064 E-mail: antony.kamakia@hhu.edu.cn, \\ antony.kamakia@ksg.ac.ke
}

Shi Guoqing

National Research Centre for Resettlement, Hohai University

8 Focheng West Road, Jiangning District 211100, Nanjing, Jiangsu, China

Tel: 86-133-0518-3575 E-mail: gshi@hhu.edu.cn

\section{Mohammad Zaman}

National Research Centre for Resettlement, Hohai University

8 Focheng West Road, Jiangning District 211100, Nanjing, Jiangsu, China

Tel: 1-604-375-0017Ｅ-mail: mqzaman.bc@gmail.com

\begin{abstract}
Zhou Junbi
National Research Centre for Resettlement, Hohai University

8 Focheng West Road, Jiangning District 211100, Nanjing, Jiangsu, China

Tel: 86-136-2158-9545Ｅ-mail: zjunbi@hhu.edu.cn, zjunbi@126.com
\end{abstract}

Received: January 30, 2018 Accepted: February 12, 2018 Published: March 9, 2018

doi:10.5296/emsd.v7i2.12561 URL: https://doi.org/10.5296/emsd.v7i2.12561 


\section{Abstract}

Kenya has adopted a comprehensive development path to accelerate and create suitable conditions for sustainable development as outlined in the "Vision 2030." A key strategy is the catalytic role of bilateral loans and finances which have increased in manifolds over the years. However, a growing and critical discourse has emerged about the social-ecological sustainability in the Chinese-financed development projects, within the context of China-Africa engagement policy. China is playing significant role in the economic growth of developing countries and in particular, critical investments in productive sectors. This paper examines the development-induced displacement and resettlement (DIDR) framework and explores the social-ecological impacts and outcomes of some selected Chinese-financed projects in Kenya. The paper also examines the various social-ecological guidelines and standards issued by Chinese authorities over-time, for their overseas investments and operations. It concludes that contemporary Chinese-financed development and investments in Kenya are resulting in increasing, improving and sustainable social-ecological outcomes.

Keywords: Development, Financing for development, Resettlement, Social safeguards, Chinese-financed development projects, Social-ecological outcomes

\section{Introduction and Objectives}

Many developing countries such as Kenya have recently embarked on major investment and infrastructure development projects in pursuit of economic growth and wealth creation. Strategic investment projects are beneficial on many grounds; however, they often displace tens of thousands of people from their lands and homes and subject them to social and economic hardship. Estimates show that about 15 million people are displaced annually by development projects around the world (Terminski, 2013). In Kenya, while an estimated 150,000 people were displaced by development projects during 1990-2009, the extent of displacement increased to about 300,000 during 2010-2015. This sharp rise in displacement is due to massive infrastructural investments financed by China, among other factors. Accordingly (Woods, 2016), China has provided development finance, bilateral loans and grants to Kenya, which rose from $\$ 630$ million in $2000-2009$ to $\$ 5$ billion in the period 2010-2015. For the Chinese financed development cum investment projects, displacement and resettlement safeguards and standards are delegated entirely to the local laws and regulations, unlike investments financed by Development Finance Institutions (DFIs) such as African Development Bank (AfDB) and World Bank (WB). In the case of DFIs, the client Country is additionally required to adhere to their stringent safeguard standards, so as to ensure effective management of the social-ecological and sustainable outcomes. As a result, social- ecological risks are greater in investments financed by China (Kirchherr et al., 2017; Kragelund, 2008). Such bilateral loans and financial agreements are largely political in nature and may not be thoroughly subjected to the legal and social-ecological safeguards. Kenya has recently enacted, an updated legal framework on social-ecological standards and safeguards for all development and investment projects so as to ensure sustainability of outcomes. However, determined to attract and bid for accelerated development finances and investments, these legal and policy requirements have been conviniently circumvented by many 
developing Countries. This is vividly discussed within the context of the paper.

Presently, there has been an upsurge of Chinese-financed investments in Kenya, particularly in the rail, road, energy and housing sectors. Development projects in such sectors trigger social-ecological impacts as well as the massive displacement and resettlement of local populations. Through an overview of two Chinese-financed projects in Kenya, this paper investigates the social impacts, particularly those geared towards adequate displacement and resettlement. It also provides an assessment of the adherence to the enhanced legal stipulations and guidelines that touch on such aspects. The paper also presents an overview of social and environmental standards and guidelines issued by Chinese authorities in recent times, and destined to ensure sustainable outcomes in their overseas investments and operations.

\section{Resettlement and Development in Kenya}

Resettlement and development in Kenya traces its roots from the colonial legacy. In 1895, Kenya was declared a protectorate under the British East African Protectorate, and the British Crown expropriated all land in Kenya, by the assumption of authority. The British Commissioner of the Protectorate then annexed the resource-rich areas and fertile highlands to white settlers for large-scale commercial extraction (Kanongo, 1987). The Colonial Government caused displacement and resettlement of indigenous peoples in Kenya through treaties and land ordinances while disregarding the social impacts in their entirety. The impact was widespread displacement and resettlement of native populations from the ancestral lands to the less arable "native reserves". After Kenya acquired independence, the first Kenyan Constitution of 1963 legitimized and entrenched the various ordinances and treaties of the Colonial era. Due to this legitimization, the Independent Kenyan Government took the initiative to resettle the displaced native populations. During the period 1965 - 1980, the Kenyan Government, through loans and grants from the World Bank and the British Government, embarked on resettlement schemes by purchasing the land from the White settler farmers to resettle many displaced indigenous populations ${ }^{1}$. There were estimated 278 resettlement schemes in Kenya as of 1984 which had resettled about a million people in various parts of the country especially in the Central, Coastal, and Rift Valley regions of Kenya (Mwaruvie, 2011; Furedi, 1989). The Government adopted a resettlement model in which the displaced persons would get land of about 10acres for market-oriented agri-business products. However, the political elites, very much aware of land as a crucial factor for socio-economic reproduction, hijacked the well-intended resettlement schemes either to appropriate huge chunks of private land for themselves at Government expense or to resettle members of their communities as a priority (Yamano and Deininger, 2005; Boone, 2011; Oucho, 2002). Resettlement then began to be associated with mistrust and sabotage in Kenya.

At the onset of the 1980s, development policy started to concentrate more on development

\footnotetext{
1 The Kenyan Government through the settlement Funds Trustee sought to resettle the displaced landless people. Every District (now Sub-County) had a squatter selection committee chaired by the District Commissioner. The Committee would forward a list of landless squatters to the National Director of Lands and Settlements who would allocate land in identified Government Resettlement schemes.
} 
projects so as to stimulate economic growth. Buoyed by agricultural commodities boom of the 1980s and supported by DFIs, Kenya embarked on many development projects especially schools, hospitals, roads, and dams. Notable development projects were Kamburu Dam (1971-74), Masinga Dam (1978-81) and Kiambere Dam (1983-87). Major highways such as the Nairobi -Meru highway were also completed in the 80s, among others (Mburugu, 1994). The Government invoked compulsory land acquisition through the Land Acquisition Act (Cap 295) of 1968, which had major shortcomings and lacked intrinsic standards depicted in international social safeguards ${ }^{2}$. Projects financed by DFIs such as AfDB and WB were only that addressed the social-ecological impacts reasonably. For projects funded by Government, compensation and resettlement was realized after the project had commenced to legitimate land and property owners only. In some instances, compensation was severely delayed, translating to uncertainty and vulnerability. Furthermore, determination and entitlement to compensation was also at the sole discretion of the Government Valuers as per the Valuers Act (Cap 532) of the laws of Kenya (GOK, 2012c). For the displaced persons without legitimate rights, police evictions without any form of compensation ensued. Coupled with the experiences of resettlement arising from past colonial era, development projects continued to conduct at a time when citizens had come to distrust Government intentions on all land-resettlement based schemes.

Many disputes and controversies have accompanied development and resettlement schemes in Kenya, because of the absence of the main international soco-ecological principles such as adequate compensation, public consultation, grievance redresses, and livelihood restoration in the policy and legal frameworks of the past. Redistribution of land and resettlement rights dominated politics, fuelling animosity between people of different tribal and political orientations, in particular during the electioneering periods. An estimated 150 sporadic and antagonistic land disputes (1960-2008) engulfed Kenya leading to continued international condemnation and preemption about the need for an amenable land and resettlement framework replete with socio-cultural and economic considerations inherent in international safeguard standards (Yamano and Deininger, 2005; Boone, 2011). For development projects, the controversies ranged from land tenure challenges, pressure from civil society groups, intense distrusts of Government intentions, uncertain \& inadequate compensation, and socio-political intrigues over rights of illegal and informal settlers ${ }^{3}$. Table 1 below shows salient examples of past investment projects and which have been associated with socio-ecological controversies in Kenya.

Table1. Past Development projects in Kenya

\begin{tabular}{|l|l|l|}
\hline DIDR Project & Year & $\begin{array}{l}\text { No. of displaced } \\
\text { persons (est) }\end{array}$ \\
\hline Kiambere Dam Project & 1983 & 7,000 \\
\hline Thika Superhighway Project & 2010 & 5,000 \\
\hline Third Nairobi Water Supply, Thika Dam and Pipeline & 1989 & 800 \\
\hline
\end{tabular}

\footnotetext{
2 Such as OP 4.12, the involuntary Resettlement Policy of World Bank.

3 These controversies were intertwined with the DIDR risks highlighted in the IRR model (Cernea, 2000).
} 


\begin{tabular}{|l|l|l|}
\hline $\begin{array}{l}\text { Forceful displacement from informal settlements in } \\
\text { the Capital City- Nairobi }\end{array}$ & 2004-2011 & 20,000 \\
\hline Forceful displacement from forests and protected areas & & \\
\hline Sururu forest reserve & 2004 & 4,000 \\
\hline Mau forest complex & 2005 & 50,000 \\
\hline Eburu forest reserve & 2006 & 40,000 \\
\hline Kipkuruene forest reserve & 2006 & 2,950 \\
\hline Embobut forest reserve & 2006 & 8,000 \\
\hline Mount Elgon National Park & 2006 & 3,000 \\
\hline Titanium Mining, Kwale & 2007 & 3,000 \\
\hline
\end{tabular}

Source: Mburugu, 1994; Sakwa, 2015; Syagga and Olima, 1996; Metcalfe, 2011; Abuya, 2013.

The Government of Kenya was forced to constitute various temporary commissions of inquiry overtime, to explore the various socio- economic considerations regarding development projects, including the largely unresolved resettlement question of the colonial era. These Commissions have been the Akiwumi Commission of 1998, the Njonjo Commission of 1999, the Ndungu Commission of 2003, and the Waki Commission of 2008 (Munubi et al., 2016). The finalized reports of all these commissions were instrumental in crafting the subsequent National Land Policy (NLP) of 2009 (GoK, 2009). The NLP set the pace for reforms in DIDR and recommended the consolidation and rationalisation of various land laws in Kenya ${ }^{4}$. The main NLP tenets were anchored in Chapter Five of the new Kenyan Constitution 2010, the Land Act 2012 (GOK, 2012a) (Amended in 2016), the NLC Act of 2012 and the Community Land Act (GOK, 2012b; GOK, 2016a).

Kenya adopted a new Constitution in 2010 (GOK, 2010), which replaced the former constitutions of 1963 and 1969. Article 40 of the Constitution declares that the Government can acquire land compulsorily for public interests but offer compensation and resettlement to the land and property owners with or without legal entitlement. Articles 67 and 68 provided for Parliament to enact a comprehensive land law (The Land Act of 2012), which repealed, consolidated and harmonized all land laws in Kenya. The land law laid the legal framework for the National Land Commission (NLC) to deal with matters of compulsory land acquisition and compensation for PAPs with legal rights. The Land Settlement Fund (LSF) Trustees established by the Land Amendment Act 2016 provides resettlement and livelihood to PAPs without legal rights including the victims of past colonial injustices. For development and investments in rural land mostly inhabited by indigenous communities, the Community Land Law 2016 secures the DIDR procedures and outcomes. It establishes criteria for management and investments in community land while protecting the rights of the vulnerable such as widows, orphans, and women. The law also requires investors to engage in sustainable community development plans and capacity building for the local communities. Further to this, Section 3 of the Land Act and section 94 of the NLP requires the NLC to initially acquire land for public purposes such as Public-Private Partnerships (PPP) and

\footnotetext{
${ }^{4}$ Article 75 of the 1963 Constitution, the Indian transfer of property Act of 1882, the Governments Lands Act -cap 280, the Wayleaves Act -cap 292 and the Land Acquistion Act -cap 29. The Act was furher amended in 2016
} 
Special Economic Zones (SEZs). The Act also applies to the discovery of minerals in Kenya ${ }^{5}$, so as to protect PAPs and rural communities from potential exploitation by activities of profit-oriented local or foreighn investors ${ }^{6}$. Also, the Government must plough-back a percentage of the revenues generated from such mining activities to the respective local County Government as part of benefit-sharing with the local communities (GOK, 2016c).

The Kenyan Parliament enacted the National Land Commission (NLC) Act of 2012 to provide for the powers and organogram of the NLC. The NLC is also the custodian of all public land in Kenya, and all Government agencies are mandated to liaise with the NLC to acquire land on their behalf and to facilitate resettlement procedures. The NLC has well-established thresholds that the public agencies must meet to implement the subsequent land acquisition. Additionally, all development projects in Kenya must subscribe to the National Environment Management Authority - NEMA Act of 1999 (revised in 2015) and NEMA regulations of 2016 (GOK, 2015; GOK, 2016b) which precede mandatory NEMA license and provide for the enviromental and social considerations and procedures for development projects ${ }^{7}$.

\section{Methodology}

So far, development projects have had their share of controversies in Kenya. To investigate the improving land-scape for socio-ecological outcomes, within the realm of Chinese-financed development projects, we review available but recent secondary materials, such as journal papers, new policies (issued by Chinese authorities), newspaper articles \& other media outlets, scholarly writings by internet-based entities and non-governmental organizations. To complement and collaborate the secondary data obtained, we conducted dedicated in-depth interviews with key informants in both Kenya and China. We adopted a SWOT-PESTEL $^{8}$ factors investigation methodology, to capture the real scenarios, to the fullest extent possible. The ensuing discussions are therefore, firmly grounded on pragmatic reflections of the primary and secondary sources of data realized.

\section{The Influx of Chinese Finance and Investments in Kenya}

Kenya is embarking on a series of mega-development projects, championed by the ambitious economic-development policy blueprint dubbed the 'Vision 2030', which hopes to elevate the country to 'high industrialized' status during the period 2008-2030. To achieve the specified economic development indicators, the blueprint integrates various approaches such as the vivid engagement of DFIs (AfDB and World Bank) and the Public-Private Partnerships (PPP)

\footnotetext{
${ }^{5}$ NLC is the custodian of all public land in Kenya. The recently enacted Mining Act of 2016 transmits ownership of land where minerals have been discovered to the Government and obligates the NLC and LSFTrustees to compensate and resettle the affected ethnic or indigenous communities.

${ }^{6}$ In the Kenyan PPP model, the Government gives free land to investors in exchange for development cum investment projects that guarantee local employment, and technological transfer.

7 The regulations and guidelines contain stringent procedures for ESIA, audit, supervision and monitoring for all development projects in Kenya. NEMA issues a conditional licence against measures fashioned in the project ESMP.

${ }^{8}$ SWOT (Strengths, weaknesses. Opportunities and Threats); PESTEL (Political, Economic, Social, Technological, Ecological and Legal) factors
} 
models advocated by the new economic development paradigms ${ }^{9}$. The document also lays special emphasis on the maintained infusion of FDI, as a means to attain coordinated multiplier effects towards the high-industrialized economy status. The Chinese investments in Kenya have also been driven by the Chinese 'One Belt, One road' initiative which is a dedicated web of transport and communication routes that inter-connect the global commercial hubs. Kenya is part of this network that is inter-linking Asian and European Countries in an intricate web of sea, rail and road routes ${ }^{10}$.

China has provided development finance and assistance to Africa since 1956. During the First Ministerial Forum for China -Africa Cooperation (FOCAC) in 2000, China committed and canceled \$10Billion in mature debt owed by Least-Developed African Countries as at 2005. Subsequently, during the 2006, 2009 and 2012 FOCAC conferences ${ }^{11}$, both parties continued to improve the China -Africa policies touching on finance, trade, social and economic cooperation, among other issues. As part of the policy output, China introduced zero-tariffs for $95 \%$ of goods from LDCs of Africa ${ }^{12}$ and set the groundwork for special development funds by Chinese banks to support strategic Chinese investments in Africa (Kragelund, 2008; Zhao, 2011). These banks were the China's EXIM Bank and China Development Bank, both of which are heavily involved in China- Africa policy-partnership and finance.

China -Africa bilateral trade has increased from $\$ 10$ billion from the year 2000 to $\$ 210$ billion in 2013. Accordingly, Chinese enterprises are increasingly shifting their focus from trade to investments (Xiaoyang and Sun, 2016). Since 2001, almost half of all China EXIM bank financing has been absorbed by Africa, and between 2001 and 2010, China's EXIM Bank provided about $\$ 65$ billion compared to $\$ 55$ billion from World Bank in the same period (Corkin, 2012). China provided a cumulative $\$ 90$ billion $^{13}$ of development finance to Africa from the year 2000-2015 (Fernholz, 2017). In 2012, China handed the keys for the new conference center to the African Union -AU, built at the cost of \$200 million in Addis Ababa, Ethiopia as a special friendship gesture towards China- Africa cooperation. China has also provided an initial $\$ 2$ billion to be invested through the AfDB (Matina, 2014). These gestures set the tempo for the increased role of Chinese friendship, partnership and investments in Africa.

Since 1964 when bilateral relations between the Kenya and China began, China has provided an estimated \$4.8Billion of development finance to Kenya. Currently, Kenya's foreign debt to China is the highest at about $\$ 3.1$ billion, as at the end of 2016 (Kuo, 2016; Herbling, 2016). In Africa, Kenya recorded the fastest rise of 47\% in FDI in 2015 (Kariuki, 2016). Chinese capital and personnel have become a common sight in Kenya. As at the end of 2015, Kenya hosted around 400 Chinese firms spread across many sectors of the economy especially in the transport, communication and construction sectors (Sanghi and Johnson, 2016). In September

\footnotetext{
${ }^{9}$ http://www.worldbank.org/en/topic/publicprivatepartnerships

${ }^{10} \mathrm{http} / / / \mathrm{blogs} .1$ se.ac.uk/internationaldevelopment/2017/01/30/the-impact-of-chinas-one-belt-one-road-initiative-o n-developing-countries/

${ }^{11} \mathrm{http} / /$ www.businessdailyafrica.com/Opinion-and-Analysis/What-Kenya-stands-to-gain-from-trade-with-the-C hinese-/539548-1464104-view-printVersion-2y6pnlz/index.html

12 Started with $60 \%$ of products from LDCs in 2010

13 http://edition.cnn.com/2016/11/21/africa/chinese-funded-railways-in-africa/
} 
2016, China opened the Chinese-African Development Fund (CADF) representative office in Nairobi, the $5^{\text {th }}$ of its kind in Africa. The objective of the CADF is assisting Chinese companies and investments in African countries (Baishun, 2016). The Kenyan Government and agencies have signed several agreements with Chinese authorities, for the financing of various public investment projects. To date, several investments have attracted Chinese FDI such as the ongoing standard gauge railway (SGR) from the port of Mombasa to the landlocked countries of Uganda and Southern Sudan.

Table 2. Some of the completed or ongoing Chinese-financed projects in Kenya

\begin{tabular}{|l|l|l|}
\hline Investment Project & Cost of Investment & Year \\
\hline Standard Gauge Railway (3-Phases) & \$4 Billion & $2014-2018$ \\
\hline Thika Super Highway (Lot 3) & \$100 Million & $2009-2012$ \\
\hline Nairobi Northern and Eastern Bypass & \$85 Million & $2009-2012$ \\
\hline Nairobi Southern Bypass & \$158 Million & $2013-2016$ \\
\hline Nairobi Western Bypass & \$180 Million & $2017-2019$ \\
\hline Fiber Optic Cable & \$60 Million & $2012-2016$ \\
\hline Drilling of Geothermal wells in Olkaria & \$195 Million & $2010-2015$ \\
\hline Moi Teaching and Referral Hospital- Eldoret & \$560 Million & $2015-2018$ \\
\hline Kenyatta University Teaching and Referral Hospital & \$100 Million & $2011-2016$ \\
\hline High Grand Falls Dam & \$1.5 Billion & $2017-2012$ \\
\hline
\end{tabular}

Source: Wangalwa, 2015; Mungai, 2016; Ngugi, 2016; MyGov, 2015.

\section{The Socio-ecological and Displacement-resettlement Outcomes}

\subsection{Case Study 1 - The Standard Gauge Railway Project}

The Standard Gauge Railway (SGR) is the largest public development project ever undertaken by the Kenyan Government since independence, both in terms of scale and number of affected PAPs. The China Road and Bridge Corporation (CRBC) is building the SGR. The public agency undertaking the project is Kenya Railways Corporation (KRC). The SGR line is expected to proceed to Uganda, Rwanda, and Burundi, with branch lines to Ethiopia and South Sudan (Wasuna, 2015). The project is expected to escalate volumes of imported goods and services from the port of Mombasa to the cities of Nairobi (Kenya), Kampala (Uganda), and Kigali (Rwanda). According to an interview with the Director of Research at National Land Commission (NLC) (Dr. Fibian Lukalo), they undertook displacement and resettlement for the affected populations and they advised the Kenya Railway Corporation to re-design and re-route the railway line from areas with dense or informal settlements. The railway project thereby expropriated about $90 \%$ of new land so as to mitigate resettlement of informal settlements (NLC, 2016b). The SGR displaced and compensated about 50,000 persons in the $1^{\text {st }}$ phase from the Port City of Mombasa to the Capital City, Nairobi. The Government through the National Land Commission used an estimated Ksh10b (\$100million) for the entire displacement and resettlement scheme (Akumu, 2014). The full disturbance, incidental and transportation costs were enjoined in the subsequent compensation package. The Kenya Railway Corporation and the National Land 
Commission formed a joint resettlement committee, in whom five representatives of affected persons were co-opted as members (KRC, 2015).

The officials interviewed established that having been the first mega project under the revamped constitutional mandate, there had been many dynamics involved but the social impacts were adequately managed. They noted that compensation was the underlying strategy for displacement and resettlement because the alternative i.e. land-for land strategy would cause dislocation of additional PAPs. Also, the legal procurement processes for land banks are lengthy for all Government Agencies. However, for public schools and related institutions $^{14}$ along the railway route, the commission had adopted a strategy in which modern facilities were erected at permanent resettlement sites, through an agreement with the Chinese-railway contractor. It was commendable that the local communities realized modern facilities which were not comparable to the former on account of resettlement or otherwise. The officials also noted that they had engaged in extensive stakeholder consultative forums through their advocacy department in order to manage complex issues such as land disputes entangled in customary and community land ownerships ${ }^{15}$. There had been other emergent issues such as Land speculation and gentrification but they noted that the Government is prepping a law focusing on Land-Value Index to curb land speculation in areas earmarked for development projects ${ }^{16}$. Cultural assets such as graves were also fully compensated after consultations with the local community leaders. Nevertheless, the commission officials interviewed expressed that they were currently experiencing shortage in staff capacity and by extension, the required expertise for resettlement management in Kenya. However, they noted that the commission was in the process of recruiting experts and also enhancing policy for post-resettlement management for sustainable development outcomes. During project construction, the Chinese contractor engaged in exemplary corporate social responsibility (CSR) by spearheading about 200 social programs including construction of boreholes, trading sheds, sports grounds, feeder roads and several donations and assistances for the surrounding communities. The Company also provided 60 undergraduate scholarships for railway engineering in China. The company launched the Railway Technology Training Centre in Voi, Kenya and trained the first batch of 300 artisans and technicians on railway construction and maintenance, as well. The construction of the $1^{\text {st }}$ Phase of the railway entailed a human resource distribution of 2000 Chinese expatriates and 8000 Kenyan specialists. Also, the company paid an estimated $\$ 550$ million directly to 934 local contractors in Kenya, who provided over 20,000 direct jobs to Kenyan laborers. The contractor has already embarked on the Second Phase of the SGR from Nairobi to Naivasha, by drilling the rift valley escarpment where it will pass through underground tunnels. The $3^{\text {rd }}$ Phase will run from Naivasha to Malaba border with Uganda (Dhahabu, 2016).

\footnotetext{
14 Eleven schools such as Mwamdudu Primary and Voi Girls Secondary Schools had been relocated. The CRBC contractor initially provided temporary structures to ensure the continuation of learning.

${ }^{15}$ Land disputes were particularly pronounced in the urban areas of Mombasa, Emali, Sultan Hamud and Nairobi, in which wide stakeholder consultations had been instrumental in resolving land and property ownership wrangles.

16 Agri-business products valuation had also been a major challenge and they noted a case in Voi, Kenya where similar but different parcels of sisal plantations had been valued differently but in fact, NLC considered the maturation and annual output levels.
} 


\section{Ml Macrothink}

Environmental Management and Sustainable Development

ISSN 2164-7682

2018, Vol. 7, No. 2

The National Environmental Management Authority of Kenya issued and monitored the license for the environmental and Social Management Plan which included sensitive national parks along the way. The Chinese investor and contractor mitigated environmental impacts by developing underpasses, viaducts and watering points for the animals and also installed upward-noise deflectors so as not to disrupt the animals below. The contractor also employed special means to preserve iconic plant species and riparian reserves scattered along the way (Omondi, 2016). Media stories abound in Kenya about intense land speculation in areas earmarked for the SGR project and are a testimony on the higher compensation standards as compared to the former (Guguyu, 2015). Kenya's Media was also awash with stories of newfound millionaires after compensation by the railway project. Politicians in the areas where affected persons were compensated had to run sensitization campaigns cautioning PAPs against wanton misusage of the monies. Some resulted to marrying second wives amidst other undesirable cash misuses. The bulk of the project affected persons received their compensation and resettlement dues between December 2015 and January 2016 (Mwakio, 2015).

\subsection{Case Study 2 - The Nairobi Southern Bypass Road Project}

The next case study is the Nairobi Southern bypass project. The case was chosen due to familiarity and the social-ecological dynamics involved. The Nairobi Southern Bypass is part of a network of ongoing road projects diverting traffic away from the central business district of Nairobi city. The road consisted of the construction of $30 \mathrm{~km}$ dual carriageway, commencing from an interchange in Mombasa- Kisumu Highway then connects back to the same highway at Kikuyu town towards Kisumu. The project was undertaken by China Road and Bridge Corporation through an Engineering, Procurement, and Construction (EPC) contract. China's EXIM Bank financed $90 \%$ of the $\$ 180$ Million project cost. The bypass has decongested the Central Business District by diverting a substantial volume of traffic out of the City Centre (Ndonga, 2016).

The public agency undertaking the project was the Kenya National Highways Authority (KeNHA). NEMA of Kenya duly approved the project, and a key ESMP provision was the erection of a wall barrier in the areas where the road passes through densely populated areas to protect and prevent the residents from crossing the road unless on designated overpasses. As indicated earlier, NLC has the legal mandate to undertake DIDR management for all

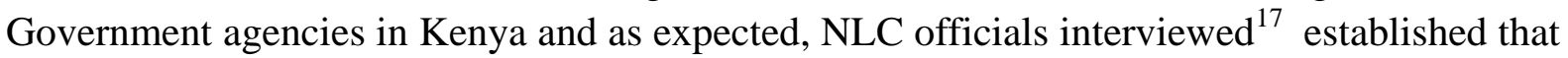
all the legal requirements for DIDR were factored extensively. The greater proportion of the project, entailed the acquisition of new land in less dense population areas. Compensation and relocation packages to an estimated 3,000 PAPs had ensued before the project commenced at a cost of about $\$ 40$ million, which was $22 \%$ of the total project cost (Mwalimu, 2013). The project acquired and compensated about 195,866 hectares of land and 86,106m2 of commercial buildings and private houses in the small towns of Kikuyu, Thogoto, Dagoretti and Lang'ata as per the approved environmental and social impact assessment report. Part of land for the Presbyterian University of Kenya was also affected. A few of the affected persons

17 Among them was the Director of Research at NLC. 
without legal rights had mini kiosks and business shades along the road ROW reserve. There were given a compensation package which factored in relocation, incidental and transport expenses. The Southern Bypass managed to avoid the biggest informal settlement in Kenya known as Kibera and the Director of Research at NLC expressed that they were in the process of converting various public lands to community lands as a policy gesture towards sustainable development of urban areas in Kenya. The National Land Commission is in partnership with Non-Governmental Organizations (NGOs) and the Land Settlement Fund trustees (of Kenya) to ensure that the process is promptly expedited. The Construction of the Nairobi Southern did not affect any cultural, archaeological or historical sites. According to in-depth interviews with highway authority officials and other road-sector stakeholders, the project has greatly enhanced the urban environment, diverted traffic from the busy Nairobi CBD and spurred socio-economic development of the city environs (KeNHA, 2010). They also commended the new embedded practice by Chinese road contractors of enjoining Corporate Social Responsibility (CSR) in the engineering works and noted that the contractor had health Centre's as part of CSR, while undertaking other projects in the city environs ${ }^{18}$. However, they expressed reservations about the DIDR delays that were occasioned by the authentication of the land and property ownership documents. This had resulted to protracted litigation processes by affected persons and NGOs.

In April 2014, the high court of Kenya had granted an injunction for the construction of the project after a petition by a local NGO- FoNNP (Friends of Nairobi National Park) on issues that touched on environmental impact. This issue was, however, addressed appropriately and due compensation paid to the Kenya Wildlife Trust Fund. The project had acquired land on the peripheral edge of the Nairobi National Park (Ndaiga, 2014). The project completion ceremony was graced by President Kenyatta of Kenya and President Magufuli of neighboring Tanzania on November 2016. The NLC and KENHA Officials interviewed concluded by observing that displacement and resettlement impacts and outcomes have greatly improved in Kenya after centralization to the NLC. In the past, they noted that there had been conflicting legislations and the various Government agencies had different procedures for DIDR thus uncertainty and vulnerability for PAPs. However, they suggested for new legislation against trespass especially on public road reserves by 'Professional PAPs' as they put it, who are very much aware about the enhanced legal and policy framework for informal affected populations and appear in several resettlement Action Plans (RAPs) for development projects accross the city environs.

\section{Chinese Regulations and Guidelines for Overseas Investments}

Since 2001, after the Beijing Summit of China-Africa forum in 2000, China encouraged its vast state-owned enterprises to go global so as to keep the pace of economic development. A prominent China in Africa has been a criticized by those that are skeptical of the Chinese African engagements, specifically arising from the premise that Chinese investments pursue ESIA policies of the recipient country, as compared to multilateral DFIs who invoke their independent safeguard policies so as to ensure favorable ESIA outcomes (Kirchherr et al.,

\footnotetext{
18 The CRBC contractor had constructed three health centres during expansion of outering road to dual carriageway in the Eastern Region of Nairobi City.
} 
2017). Western leaders have accused China of downplaying efforts to promote human rights, democracy, and good governance in Africa. China has invested in disreputable African regimes such as Sudan, Guinea, Angola, Zimbabwe, and Congo, sometimes based on susceptible factors such as preference by political elites (Bradley et al., 2016; Zhao, 2011). As far as ESIA is concerned, Chinese investments in Africa do not have a credible track record. Lack of transparency and circumventing of environmental and social management plans (ESMP) which underpin international investment models has been a major weakness. The Western leaders and media have also been concerned about ESIA safeguards in sensitive Chinese investments such as timber logging in Mozambique, Gibe 111 Dam in Ethiopia, and Melowe Dam in South Sudan (Xiaoyang and Sun, 2016). There is also an ongoing debate about genuine Chinese desire and willingness to develop Africa or the insatiable appetite and access to vast raw materials. China's mode of investment financing differs from the western models where finance is extended directly to Chinese Corporations, in an Engineering, Procurement, and Construction (EPC) contracts for the development cum investment projects in developing Countries. Scholars have further argued that this approach reduces or bypasses local partnerships, stakeholder consultation, and civil society engagement, especially in recipient Countries lacking robust ESIA and DIDR frameworks (Kragelund, 2008).

However, China has significantly enhanced its SIA and DIDR policy framework for overseas investments over the years. Since 2002, the National Reform and Development Commission of China issued several guidelines ${ }^{19}$ that obligated inclusion of SIA for local investment projects. Adverse social outcomes indicated that SIA implications were not fully integrated into past development projects hence impoverishment of PAPs, especially Chinese rural farmers (Price, 2016). This internal process triggered the same trend for China's overseas investments. The Chinese Government introduced a raft of similar guidelines for overseas investments. These guidelines include the New Guide for Chinese Contractors (2012), Green Credit Guidelines in the Banking Sector (2012) and the Guidelines for Environmental Protection in Foreign Investments and Cooperation (2013). The guidelines oblige Overseas Chinese contractors and investors to adhere to local and international ESIA and DIDR safeguard standards before financing by China-Africa policy Banks. The Chinese International Contractors Association also issued the Guide on Social Responsibilities for Chinese International Contractors (2012) which emphasizes on CSR in foreign investment and operations. This guide is equivalent to the United Nations Global Compact and/or ISO 26000. The Government of China also amended its Penalty law in 2011 to punish unethical practices such as corruption by individual Chinese officers conducting overseas investments and operations. In Oct 2014, The China Chamber of Commerce also issued Social Responsibility Guidelines for Chinese Corporations engaged in Foreign Mining Investments (Price, 2016; Xiaoyang and Sun, 2016; Kirchherr et al., 2017). It is from these dimensions that Chinese firms investing in overseas operations have initiated a process of internalizing international ESIA and DIDR safeguard standards.

The China-Africa policy financiers are at the forefront in enforcing the regulations. In 2008, a 19 Such as the Interim Measures (2012) and Social Stability and Risk Assessment of Major Capital Projects of
2013. 
local NGO in Gabon, filed complaints on adverse and far-reaching impacts in Loango National Park, against SINOPEC, a major State-Owned Oil Corporation in China and subsequently, China's EXIM Bank suspended the financing of the project. Similarly, in 2011, the Bank also suspended finance for an hydropower investment project in Myitsone-Myanmar amidst ranging ESIA concerns. In all cases, the losses for the Chinese investors were enormous, forcing them to engage local civil society groups for the resumption of the projects. Indeed, major Chinese Multinational Corporations such as SinoHydro, the biggest Dam Contractor in the World, have adopted International Finance Corporation (IFC) safeguards standards, as the minimum standards for overseas investments (Kirchherr et al., 2017; Xiaoyang and Sun, 2016; Price, 2016). In December 2015, Chinese leaders' present at the Forum on China -Africa Cooperation in Johannesburg, South Africa countered allegations that the Chinese interests are bent on extracting raw materials but rather a desire to see Africa provide a bigger partnership (Onishi, 2015). A significant output of the forum was the Johannesburg Action Plan (2016-2018) in which China and Africa jointly committed to implementing the China-Africa Green Innovation Project to manage Environmental and Social Concerns inherent in investment projects (RoC, 2015). China also committed to build five transportation universities in Africa so as to transfer technical and engineering skills (Sanghi and Johnson, 2016).

During the sidelines of the conference on Hydropower Assessment Protocol (June 2017) hosted by the National Research Center on Resettlement (NRCR), in China, the authors had the opportunity to conduct detailed interviews and focus group discussions with Chinese Multinational Hydropower Corporations ${ }^{20}$. The authors adopted a SWOT methodology to analyze the various PESTEL ${ }^{21}$ factors that affect environmental and social impacts in China's overseas investments. The officials noted that many countries had diverse legal and policy frameworks, which lack clarity about the party responsible for displacement and resettlement. They even cited instances when new laws were published when project is already at construction stage thus presenting complications' for the Chinese investors. They continued to note that Countries with centralized environmental and social mitigation frameworks such as Kenya, realized better operational efficiency and social outcomes, both for the investor and the local communities. The conference participants proposed that Chinese embassies in various Countries should publish an inventory of legal, political and cultural conditions in their respective websites so as to guide Chinese investments at the initial feasibility stages. The conference noted that Chinese Multinational Corporations attain the best investment and social outcomes when they are inclined towards internationally acclaimed standards (Nordensvard et al. 2015). This sentiments are supported by Kirchherr et al. (2017) in their study about Chinese investments in Myanmar, Laos, and Cambodia (Kirchherr et al. 2017). They argue that Chinese investors are even finding it less costly to adopt the international standards as compared to non-adoption. Reciprically, the Chinese

\footnotetext{
20 The conference was hosted between $5^{\text {th }}-9^{\text {th }}$ June 2017 , by the NRCR at Hohai University China. The authors conducted interviews and also participated in focus group discussions. The purpose of the conference was to share ideas and suggest policy recommendations for ESIA and DIDR in China's overseas hydropower investments.

21 SWOT (Strengths, Weaknesses, Opportunities and Threats); PESTEL (Political, Economic, Social, Technological, Environmental and legal) factors.
} 
Multinational Corporations officials reached out to the international community for the enforcement of international media and NGOs standards. Presumably, the international media and NGOs are hostile to Chinese investors. As such, when the Chinese investors sub-contract to local companies to enhance social outcomes and partnerships, and the local company falls back on labour payments, the Chinese investor is held to disrepute and attempts to provide counter evidence are thwarted by the international media and NGOs. In Kenya, the local media had popularized the exclusion of local suppliers by the SGR, but in reality, the project standards forced the local suppliers to upgrade the quality of their products such as cement to meet the engineering requirements. Sanghi and Johnson (2016) recognize the significant role that China is playing in the economic growth of developing countries such as Kenya. These include critical investments in productive sectors, supply of cheap intermediate inputs, technology transfer and local employment ${ }^{22}$. Chinese led multilateral investment bank- AIIB has also produced an environmental and social framework that emblazes international DIDR standards (AIIB, 2016). The International community is now changing perception that China has shown optimism in improving economic, environmental and social outcomes for the developing countries (Axel et al., 2015).

The current opinion of the World Bank and economists all over the world is moving from that of tackling poverty directly by economic aid to the one of investing in productive sectors such as energy, roads and railway sectors. The realization of rapid economic development in successful Western and Asian countries was ultimately vested in productive investments and not aid. This approach has proved to eliminate poverty much faster than the direct methods (Brautigam, 2011; The Economist, 2015). Upcoming Chinese-Kenyan investments in projects such as the Special Economic Zones (SEZs) are therefore very crucial in addressing emerging social concerns such as youth unemployment. One controversial aspect, however which has dogged Chinese investments in Kenya is cost differentials. The Kenyan SGR railway costs an average of \$8Million per kilometer whereas in neighboring Ethiopia and Tanzania, it has costed \$4.6Million and \$2.75 million per kilometer respectively. Even when other factors might contribute to this occurrence, the cost disparities are relatively wide (Ndii, 2017). This is an emerging issue that Chinese authorities must dissect before it escalates to become a media reference point regarding China- Africa engagements. International subject experts are also calling for the consolidation of the Chinese guidelines issued by different Government agencies and authorities (Price, 2016).

\section{Conclusion and Way Forward}

This paper analyzed the Chinese investments, within the realm of the environmental and social framework and outcomes in Kenya. The review and analysis of the social-ecological impacts of Chinese-financed projects established that resettlement activities are adequately aligned to the Kenyan policy and legal frameworks, which have been recently enhanced towards the international standards, such as the ones propagated by world bank and other multi-lateral financial institutions. These social-ecological safeguards are enforced and

${ }^{22}$ China has provided about 400 full scholarships to Kenyans by end of 2016. In 2011, China provided a grant of \$6Million for Mama-Lucy Hospital and \$12Million for the Confucius Institute at the University of Nairobi, Kenya. China has also provided various aid packages to combat disasters, disease outbreaks etc. 
supervised by the National Environmental Management authority and the National Land Commission of Kenya. The displacement and resettlement risks as expounded by the IRR model $^{23}$ are anticipated and reasonably addressed within the enhanced DIDR framework and dimensions in Kenya. Any foreign investments whether Chinese or otherwise have to initiate and progress under the umbrella of the EMCA, Land, Community Land and NLC acts thereby ensuring favorable DIDR outcomes for PAPs. The paper has also analyzed two mega Chinese-financed development projects which abhorred socio-ecological safeguards to the fullest extent of the Kenyan Laws and international standards. China has also ratified standardized guidelines for overseas-bound investment operations and displaced populations, local NGOs, Civil Societies and Governments should utilize them to negotiate with Chinese-financed investments in Kenya and beyond. This will produce sustainability in development outcomes such as those inherent in World-Bank financed projects or other multi-lateral financiers with standardized social-ecological safeguards.

China is playing a significant role in the economic growth and critical investments in productive sectors, of developing countries such as Kenya. The main aim of development projects in Kenya should be prosperity with desirable environmental and socio-economic outcomes. Significant Chinese investments that entailed massive displacement and resettlement such as the Standard Gauge Railway (SGR) as discussed have come at a time when Kenya has instituted far-reaching reforms to its legal frameworks. Its institutional system is fronting the "twin resettlement model" where resettlement is done as a separate project from the Government agency implementing the displacement. World Bank "twin model" financed- projects such as the Dasu Dam in Pakistan shows higher success rate for displacement and resettlement outcomes (World Bank, 2014). Many countries approach development projects in such a way that different agencies in the various sectors implement their own resettlement schemes. A major setback of this approach is the different standards and results depending on the capacity and the source of funds. In contrast, this has centralized to the National Land Commission in Kenya.

However, Kenya's framework has a notable weakness in the sense that, cash compensation rather than resettlement with development (RwD) is the overriding strategy pursued by the current framework. The RwD approach yields sustainable outcomes because resettlement is carried out as a long term development project exceeding 10years, with comprehensive livelihood restoration and benefit-sharing mechanisms. Due to various social-political dynamics unique to Kenya coupled with a shortage of land banks ${ }^{24}$, cash compensation is the preferred mode. Cash compensation, however, may lead to increased investments and purchase of consumer goods but not sustained livelihoods. As discussed earlier, there was wanton misusage of railway compensation monies, and this amplifies the common adage that, the availability of compensation does not necessarily guarantee its productive use. Since displacement and resettlement disrupts both intra- and inter-community social networks, people in the informal sector have a greater probability of losing income than those with formal sector jobs (Satiroglu and Choi, 2015). It is paramount, therefore, to scale-up the

\footnotetext{
23 Impoverishment Risks and Reconstruction (IRR) by Cernea, 2000.

${ }^{24}$ Land Banks in Kenya are appropriated by NLC over time.
} 
Kenyan legal and policy frameworks for social-ecological impacts so as to realize RwD. The concerned authorities in Kenya also should thoroughly enforce social-ecological audits, supervision and tracking as depicted in law so as to ensure sustained positive outcomes for development projects. The current framework can also be enhanced to integrate independent, technology-based monitoring and grievance redress systems that provides real-time data to all stakeholders $^{25}$. Kenya is implementing the National Lands Information Management System (NLIMS), and this offers a unique opportunity to integrate into the platform.

There are also the whole new Environmental and Social framework (ESF) frameworks, being advanced by African Development Bank and World Bank, which aim to scale-up environmental and social safeguards for client Countries. This framework will boost ecological and social outcomes for DIDR investments undertaken in developing countries. Between 2011 and 2014, Chinese authorities, China development bank and DFID-UK signed Memorandum of Understanding (MoU) that hopes to foster partnerships and trilateral cooperation for development finance while achieving goal number 11 and 17 of the Sustainable Development Goals (Especially goals no.11 and 17 of the SDGs) as crafted by the United Nations, for developing countries. A recent evaluation study by the Institute of Development Studies-United Kingdom, commended such synergies that complement and influence policy processes for sustainable development in developing countries (Gu et al., 2017). In April 2016, the AIIB and World Bank also signed an agreement synonymous to a co-financing framework that enhances supervision and management of procurement and social-ecological procedures

(http://www.worldbank.org/en/news/press-release/2016/04/13/world-bank-and-aiib-sign-firstco-financing-framework-agreement). Global development partners should ameliorate and deepen such initiatives. The paper suggests for research on the Chinese-financed development projects and the social-ecological outcomes in other developing countries.

\section{Acknowledgements}

The authors express their gratitude to the staff, support and facilities accorded by the National Research Centre for Resettlement, China and the National Land Commission, Kenya.

\section{References}

Abuya, WO. (2013). What is in a Coconut? An Ethnoecological Analysis of Mining, Social Displacement, Vulnerability, and Development in Rural Kenya. African Studies Quarterly 14. [Online] Available http://www.africa.ufl.edu/asq/v14/v14i1-2a1.pdf (12th Sep. 2016)

AIIB. (2016). Environmental and Social Framework. [Online] Available at: https://www.aiib.org/en/policies-strategies/operational-policies/environmental-social-framew ork. html (11th Sep. 2017)

Akumu, W. (2014). Kenya railway project starts amid controversy. The East African. Nairobi: Nation Media Group LTD.

\footnotetext{
25 This has successively been tried and tested in China. The Director of Research at NLC also noted that gender inclusivity in DIDR can also be tracked and monitored by the same system.
} 


\section{Macrothink}

Environmental Management and Sustainable Development

ISSN 2164-7682

2018, Vol. 7, No. 2

Axel, D., Andreas, F., Bradley, P., et al. (2015). Many in the West fear Chinese 'aid' to Africa. They're wrong. Here's why. The Washington Post. Washington, DC: The Washington Post. [Online]

https://www.washingtonpost.com/news/monkey-cage/wp/2015/10/20/many-in-the-west-fearchinese-aid-to-africa-theyre-wrong-heres-why/?utm_term $=.5751 \mathrm{dbeeb52b}\left(4^{\text {th }}\right.$ Dec 2017$)$

Baishun, L. (2016). China's development fund, Kenyan Government sign deal on housing project. [Online] Available at:

http://news.xinhuanet.com/english/2016-09/23/c_135706520.htm ( $3^{\text {rd }}$ June 2016)

Boone, C. (2011). Politically allocated land rights and the geography of electoral violence: The case of Kenya in the 1990s. Comparative Political Studies, 44, 1311-1342. https://doi.org/10.1177/0010414011407465

Bradley, P., Roland, H., Axel, D., et al. (2016). Chinese aid is helping African economies, but not in the places that need it most. The Washington Post. [online] Available https://www.washingtonpost.com/news/monkey-cage/wp/2016/10/07/is-chinese-aid-powerin g-economic-growth-in-africa-yes-but-our-data-show-unequal-development/?utmterm $=.19 f d 10541 \mathrm{cc} 0\left(20^{\text {th }}\right.$ Jan 2017).

Brautigam, D. (2011). China in Africa: What can Western donors Learn. A report for the Norwegian Investment Fund for Developing Countries (NORFUND). [online] Available https://www.norfund.no/getfile.php/133986/Bilder/Publications/Norfund_China_in_Africa.pd f (12th Jan. 2018).

Cernea, M. M. (2000). Risks, safeguards and reconstruction: a model for population displacement and resettlement. Economic and Political Weekly: 3659-3678. [online] Available http://www.jstor.org/stable/4409836?seq=1\#page_scan_tab_contents $\left(2^{\text {nd }}\right.$ Oct. 2017)

Corkin, L. (2012). Redefining foreign policy impulses toward Africa: The roles of the MFA, the MOFCOM and China Exim Bank. Journal of Current Chinese Affairs 40: 61-90. [online] Available https://journals.sub.uni-hamburg.de/giga/jcca/article/view/480/478 (16th Dec. 2017).

Dhahabu. (2016). China Road and Bridge employs 38, 000 locals in SGR. Available at: http://www.dhahabu.co.ke/2016/03/28/china-road-bridge-employs-38-000-locals-sgr/. $\quad\left(4^{\text {th }}\right.$ Dec. 2017).

Fernholz, T. (2017). Revealed: $\$ 75$ billion in previously secret Chinese aid to Africa. [online] Available at:

https://qz.com/898730/google-employees-are-protesting-trumps-immigration-ban-with-a-wal kout/. (28 $8^{\text {th }}$ Nov. 2017).

Furedi, F. (1989). The Mau Mau War in Perspective., London: James Currey.

GOK. (2007). Vision 2030 of Kenya. In: Development MoPa (ed). Nairobi, Kenya: Government Printer. 
GOK. (2009). Sessional Paper No. 3 on National Land Policy. No. 3 of 2009. Nairobi, Kenya: Ministry of Land, Housing and Urban Development.

GOK. (2010). The Constitution of Kenya. In: Attorney General (ed) Revised Edition 2010 ed. Nairobi, Kenya: Government Printer.

GOK. (2012a). The Land Act. In: General A (ed) Revised Edition 2012 ed.

GOK. (2012b). The National Land Commission Act. In: General TA (ed) CHAPTER 5D. Revised Edition 2014 [2012] ed. Nairobi, Kenya: National Council for Law Reporting.

GOK. (2012c). The Valuers Act. Chapter 532. Nairobi, Kenya: National Council for Law Reporting.

GOK. (2016a). The Community Land Act. In: General A (ed) Kenya Gazette Supplement No. 148 (Acts No. 27). Nairobi, Kenya: Government Printer.

GoK. (2016b). The Environmental (Impact, Assessment And Audit) Regulations 2003 (Amendment 2016). [online] Available at: www.nema.go.ke/index.php?option=com_ phocadownload\&view=category \&download=315:legal-notice-no-149-155-environment-act \& id =3:legislationandpolicies\&Itemid=319. $\left(29^{\text {th }}\right.$ May. 2016).

GOK. (2016c). The Mining Act. No. 12 of 2016. Revised Edition 2016 (2012) ed. Nairobi: National Council for Law Reporting.

Gu, J., Holmes, P., Rollo, J., et al. (2017). China-UK-Africa Trilateral Cooperation on Trade and Investment: Prospects and Challenges for Partnership for Africa's Development. IDS. [online] Available

http://www.ids.ac.uk/publication/china-uk-africa-trilateral-cooperation-on-trade-and-investm ent-prospects-and-challenges-for-partnership-for-africa-s-development (4th Dec. 2017)

Guguyu, O. (2015). Lapsset investors urge government to tame rocketing land prices. Nation Newspaper. Nairobi, Kenya: Nation Media Group.

Herbling, D. (2016). Mega projects double public debt burden to Sh3.56trn in September Business Daily. Nairobi, Kenya: Nation Media Group.

Kanongo, T. (1987). Squatters and the Roots of Mau Mau, 1960-1963, Athens: Ohio University Press.

Kariuki, J. (2016). Kenya posts fastest rise in foreign direct investments. Daily Nation. Nairobi: Nation Media Group.

KeNHA. (2010). ESIA Report for the Prorposed Nairobi Southern Bypass. Project Proponent: Kenya National Highways Authority and China Roads and Bridges Corporation. Nairobi: African Waste and Enviroment Management Centre.

Kirchherr, J., Matthews, N., Charles, K. J., et al. (2017). "Learning it the Hard Way": Social safeguards norms in Chinese-led dam projects in Myanmar, Laos and Cambodia. Energy Policy, 102, 529-539. https://doi.org/10.1016/j.enpol.2016.12.058 
Kragelund, P. (2008). The Return of Non - DAC Donors to Africa: New Prospects for African Development? Development Policy Review, 26, 555-584.

htpps://doi.org/10.1111/j.1467-7679.2008.00423.x

KRC. (2015). ESIA Study Report for the Proposed Re-Alighnment of the SGR within Nairobi National Park Nairobi, Kenya: LIMCOM AFRICONSULTANTS.

Kuo, L. (2016). China now owns more than half of Kenya's external debt. [online] Available at: https://qz.com/707954/china-now-owns-more-than-half-of-all-of-kenyas-debt-2/. $12^{\text {th }}$ Dec. 2017)

Matina, S. (2014). China Launches \$2 Billion African Development Fund. The Wall Street Journal. Dow Jones \& Company. [online] Available https://www.wsj.com/articles/china-launches-2-billion-african-development-fund-140077071 8 16th March 2017).

Mburugu, E. K. (1994). Dislocation of settled communities in the development process: The case of Kiambere hydroelectric project. World Bank Technical Paper: 49-49.

Metcalfe, V., Pavanello, S., \& Mishra, P. (2011). Sanctuary in the City?: Urban Displacement and Vulnerability in Nairobi: Humanitarian Policy Group (HPG), Overseas Development Institute (ODI). [online] Available

https://www.alnap.org/help-library/sanctuary-in-the-city-urban-displacement-and-vulnerabilit y-in-nairobi (13th July 2016)

Mungai, R. (2016). Is China Railroading Kenya Into Debt? - People in Malaysia, Vietnam, Laos, Singapore, Thailand, The Philippines and Elsewhere Need to Take a Look. [online] Available at:

https://johnib.wordpress.com/2016/10/08/is-china-railroading-kenya-into-debt-people-in-mal aysia-vietnam-the-philippines-and-elsewhere-need-to-take-a-look/. $12^{\text {th }}$ Feb. 2017).

Munubi, S. L., Mwangi, W., \& K'Akumu, O. (2016) Involuntary resettlement policy and praxis in Kenya: Conforming with the national land reforms. Journal of Basic and Applied Research, 16(4), 278-291.

https://papers.ssrn.com/sol3/papers.cfm?abstract_id=2838606 (12 $2^{\text {th }}$ Sep. 2017).

Mwakio, P. (2015). How new Standard gauge railway millionaires are spending compensation cash. Standard Newspaper. Nairobi, Kenya: Standard Media Group.

Mwalimu, E. (2013). Massive evictions as State expands road networks. [online] Available at: http://www.mintoreal.com/news/240-massive-evictions-as-state-expands-road-networks (27th Aug. 2016).

Mwaruvie, J. (2011). The Ten Miles Coastal strip: An Examination of the Intricate Nature of Land Question at Kenyan Coast. International Journal of Humanities and Social Science, 1(20), 176-182. [online] Available

http://www.ijhssnet.com/journals/Vol_1_No_20_December 2011/17.pdf (3rd May 2016).

MyGov. (2015). China's financial support to Kenya tops Ksh488.8 billion. [online] Available 
at: http://www.mygov.go.ke/?p=3832. $4^{\text {th }}$ Dec. 2017).

Ndaiga, H. (2014). Nairobi Southern Bypass. Construction Bussiness Review. Nairobi, Kenya: Samscom Media Group.

Ndii, D. (2017). Are mega projects worth billions spent? Nation Newspaper. Nairobi, Kenya: Nation Media Group.

Ndonga, S. (2016). Kenya: Construction of Southern Bypass to Be Complete By June 30. AllAfrica. [online] Available http://allafrica.com/stories/201606231029.html (20 ${ }^{\text {th }}$ Nov. 2016).

Ngugi, B. (2016) Construction of Sh17bn Western Bypass set to start. Daily Nation. Nairobi: Nation Media Group.

NLC. (2016b). Devolving Land Governance. National Land Commission, Kenya. [online] Available at

http://landcommission.go.ke/media/erp/upload/national_land_commission_2015-2016_annua 1_report.pdf (3rd May 2017).

Nordensvard, J., Urban, F., \& Mang, G. (2015). Social innovation and Chinese overseas hydropower dams: The nexus of national social policy and corporate social responsibility. Sustainable development, 23, 245-256. https://doi.org/ 10.1002/sd.1591

Omondi, D. (2016). SGR contractor bids to win hearts with projects along rail line. The Standard. Nairobi: Standard Group.

Onishi, N. (2015). China Pledges $\$ 60$ Billion to Aid Africa's Development. The New York Times. The New York Times Company. [online] Available https://www.nytimes.com /2015/12/05/world/africa/china-pledges-60-billion-to-aid-africas-development.html (14th May 2017)

Oucho, J. O. (2002). Undercurrents of ethnic conflicts in Kenya: Brill.

Price, S. (2016). Social Impact Assessment in China and its Overseas Investments: Some Recent Developments. Assessing the Social Impact of Development Projects. Springer, 129-151. https://doi.org/10.1007/978-3-319-19117-1_9

RoC. (2015). The Forum on China-Africa Cooperation Johannesburg Action Plan (2016-2018). 10-Dec-2015 ed.: Ministry of Foreighn Affairs, China. [online] Available http://www.fmprc.gov.cn/mfa_eng/wjdt_665385/2649_665393/t1323159.shtml (4th Dec. 2017).

Sakwa, G. L. (2015). Social and economic impacts of involuntary resettlement during large scale water infrastructure development: the case of Thika dam. University of Nairobi. [online] Available http://erepository.uonbi.ac.ke/handle/11295/93923 (4th May 2016).

Sanghi, A., \& Johnson, D. C. (2016). Deal or no deal: strictly business for China in Kenya? World Bank Policy Research Working Paper. [online] Available http://documents.worldbank.org/curated/en/801581468195561492/Deal-or-no-deal-strictly-b usiness-for-China-in-Kenya (27th June 2017). 


\section{Macrothink}

Environmental Management and Sustainable Development

ISSN 2164-7682

2018, Vol. 7, No. 2

Satiroglu, I., \& Choi, N. (2015). Development-Induced Displacement and Resettlement: New Perspectives on Persisting Problems: Routledge.

Syagga, P. M., \& Olima, W. (1996). The impact of compulsory land acquisition on displaced households: The case of the Third Nairobi Water Supply Project, Kenya. Habitat International, 20, 61-75. https://doi.org/10.1016/0197-3975(95)00034-8

Terminski, B. (2013). Development-induced displacement and resettlement: Theoretical frameworks and current challenges. Development, 10, 101. [online] Available http://dlc.dlib.indiana.edu/dlc/handle/10535/8833 (2nd Oct. 2016).

The Economist. (2015). Asia's scramble for Africa; India, China and Japan are battling for influence. The Economist. Nairobi, Kenya: The Economist Group.

Wangalwa, E. (2015). Kenya owes China Billions. [online] Available at: http://www.cnbcafrica.com/news/east-africa/2015/03/31/kenya-china-debt/. (28 ${ }^{\text {th }}$ Dec. 2016).

Wasuna, B. (2015). Inside Makuenis Battle over the Pricing of Railway Land. Business Daily Africa. Nairobi, Kenya: Nation Media Group LTD.

Woods, N. W. (2016). Development goals are an uphill task. Nation Newspaper. Nairobi: Nation Media Group, 18.

World Bank. (2014). Social and Resettlement Management Plan. [online] Available at: http://documents.worldbank.org/curated/en/925121468087848248/Social-and-resettlement-m anagement-plan. $7^{\text {th }}$ April 2016).

Xiaoyang, T., \& Sun, I. Y. (2016). Social Responsibility Or Development Responsibility-What Is the Environmental Impact of Chinese Investments in Africa: What Are Its Drivers, and What Are the Possibilities for Action. Cornell Int'l LJ 49: 69. [online] Available http://www.lawschool.cornell.edu/research/ILJ/upload/Xiaoyang-Sun-final.pdf (4th July 2017).

Yamano, T., \& Deininger, K. (2005). Land conflicts in Kenya: causes, impacts, and resolutions. Foundation for Advanced Studies on International Development/National Graduate Institute for Policy Studies. The World Bank: 28.

Zhao, S. (2011). China's African Relations and the Balance with Western Powers. China and the European Union in Africa: Partners or Competitors: 61-77. [online] Available http://link.lib.umanitoba.ca/portal/China-and-the-European-Union-in-Africa--partners/ gERSfSTsCSw/ (25 ${ }^{\text {th }}$ Dec. 2017).

\section{Copyright Disclaimer}

Copyright for this article is retained by the author(s), with first publication rights granted to the journal.

This is an open-access article distributed under the terms and conditions of the Creative Commons Attribution license (http://creativecommons.org/licenses/by/3.0/). 